\title{
LAND-SNAIL DIVERISTY IN A THREATENED LIMESTONE FORMATION IN ODUKAPNI, CROSS RIVER STATE, NIGERIA.
}

\author{
O. C. OKE, F. I. ALOHAN AND W. ABHULIMEN
}

(Received 13 February 2007; Revision Accepted 2 May 2007)

\begin{abstract}
The land snail fauna of a threatened limestone formation in Odukpani is studied using a combination of direct search (for 1hour) and litter-sieving techniques. A total of 425 specimens comprising 52 species/morphospecies belonging to eight molluscan families were collected from seven sample plots. Each plot yielded between 19 and 98 specimens (mean 70.5; standard deviation 31.72). The diversity per plot ranged from 7 to 34 (mean 19.14, standard deviation 9.74). Extrapolation suggests that the true diversity lies around 72 species. Our study shows that the diversity in Odukpani limestone cave can be high in spite of low abundance given the small samn!e size. Several species were found that had previously not been known from other areas in Nigeria and may be new to science. The conservation of the limestone cave is advocated so as to protect its unique biodiversity.
\end{abstract}

KEYWORDS: Mollusca, diversity, limestone, Odukpani, Nigeria

\section{INTRODUCTION}

Limestone formations in tropical rainforests are renowned for their abundance and diversity of ground-dwelling macroinvertebrates, including land-snails (Boycott 1934, Schiltuizen et al 2003, Orsten et al, 2005). Often, these limestone formations are threatened by natural and anthropogenic agents. They are subject to severe weathering by high rainfall, humidity, and biological productivity (Crowther, 1987). They are also threatened by the exploration of commercial cement companies. In the process of exploration for cement many of the unique land snail faunas and other invertebrates are likely to be destroyed before they are known or before adequate measures can be taken for their protection. Unfortunately, land snail communities are among the most sensitive known to anthropogenic and other disturbances (Lyeard et al. 2005). Even as the conservation importance of these taxa and sites are being realized, they are being lost from development, agriculture, forestry, quarrying and recreational pressures (Nekola et al. 1996). Worldwide, nonmarine molluscs have the largest number of documented extinctions, and of IUCN-listed threatened species, of any major group (Groombridge, 1993; Ponder, 1997). Despite this, as with other invertebrate groups, they attract little or no attention from organizations and government departments concerned with conservation.

In Nigeria, limestone outcrops are few and scattered over the landscape. The limestone formation in Odukpani near Calabar, Cross River State, Nigeria is one of the remaining limestone outcrops that are yet to be exploited and there is growing pressure on the government to start commercial exploitation. In this report we assess the species richness of the tropical rainforest land snail fauna in the limestone cave in Odukpani so as to determine the full extent of their diversity. Through this research, a better understanding of the nature of the terrestrial gastropods from this little known limestone cave area is possible. This will also serve as baseline information for conservation of the limestone and its biodiversity in Nigeria and other parts of the world.

The Study Area (Fig. 1)

Our study was conducted in a heterogeneous primary forest in the lime stone cave at Etankpini (Latitude $5^{\circ} 7^{\prime} \mathrm{ON}$ Longitude $8^{\circ} 24^{\prime} \mathrm{OE}$, altitude $104 \mathrm{~m}$ above sea level) near Odukpani in Cross River State, Nigeria. 


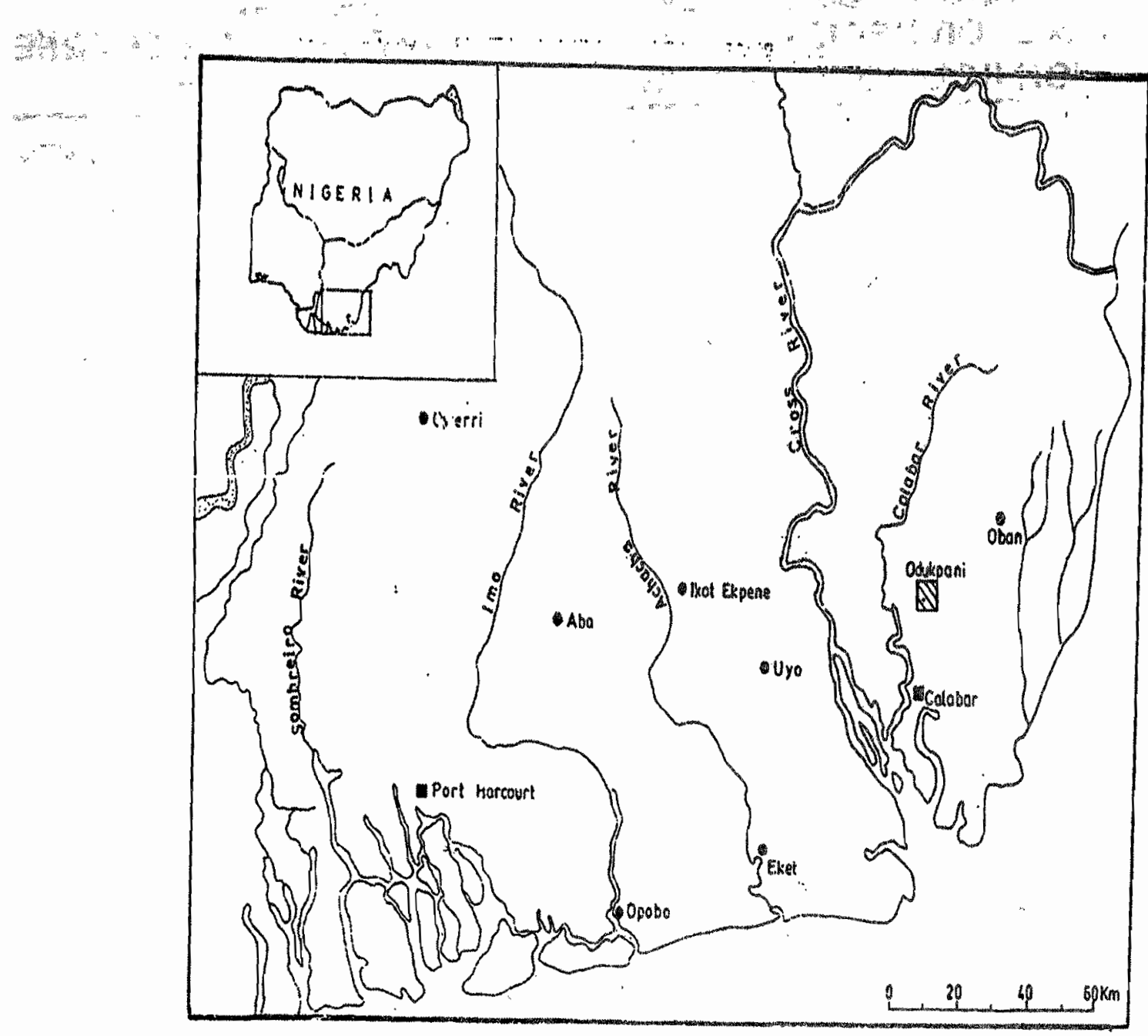

Figure 1: Map of study area where samples were collected in Odukpani, south -eastern Nigeria (inset).

\section{METHODS}

SE.npling was carried out in a limestone cave and surrounding forest near Odukpani on Mzy 30, 2006 using a combination of direct search ("or 1hour) and litter-sieving techniques. Seven plots of $10 \mathrm{~m} \times 10 \mathrm{~m}$ cach were selected within the cave. At each plot we intensely searched for snails and slugs in the soil and leaf litter. Searching was done during two person-hours (i.e. two searchers active for one hour) using a head-torchlight. In addition, at each plot we collected an average of 10 litres of litter and top soil sample from ten randomly selected sites $(1 \mathrm{~m} \times 1 \mathrm{~m}$ each). Litter samples and top soil were collected into polythene bags for transportation to the laboratory. Upon arrival in the laboratery, the samples were dried and exhaustively searched for lo.1 molluscs. All snails, siugs and shell fragments encountered as well as those collected alive in the field were preserved in $70 \%$ ethanol after drowning.

The measure of diversity used in this study are overall species richness (S) and Whittaker's index (I), which is the total number of species recorded (S). divicied by the mean number of species per site (a), provicing a measure of diversity difference among sites (Magurran, 1080; Cameron, 1992; Schilthuizen \& Rutjes, 2001). Estimatio : of true diversity was carried out by performing 100 randomisations on the data from the 7 plots, and calculating $S$ using the chao 2 and second-order jackknife richness estimators in the program Estimates7.5 (Colwell, 2005).

\section{RESULTS}

Table 1 shows the occurrence of species of land snails in each sample plot. A total of 425 specimens comprising 52 species/morphospecies belonging to eight molluscan families were collected from the seven sample plots. Twenty-nine specimens could not be classified, including ten juvenile Subulinidae and nineteen juvenile Streptaxidae. Fourteen species $(26 \%)$ occur as singleton and nine of these were streptaxids including five species of Gulella. Each plot yielded between 19 and 98 specimens (mean 70.5; standard deviation 31.72). The diversity per plot ranged from 7 to 34 (mean 19.14, standard deviation 9.74). The number of species detected correlates with the number of individuals $(r=0.982 ; n$ $=7 ; \mathrm{P}<0.05$ ). Whittaker's Index I amounted to 2.72 (calculated as the overall species richness $S=52$ divided by the mean number of species per plot $\alpha=19.14)$. This figure indicates substantial amcunt of beta diversity, i.e., heterogeneity among plots. The richest plot had about $50 \%$ of the site fauna while the pocrest had only $13 \%$. As species are pooled together, the species accumulation curve did not approach an asymptote, but continued to rise with increases in sample numbers (fig. 2 ): 

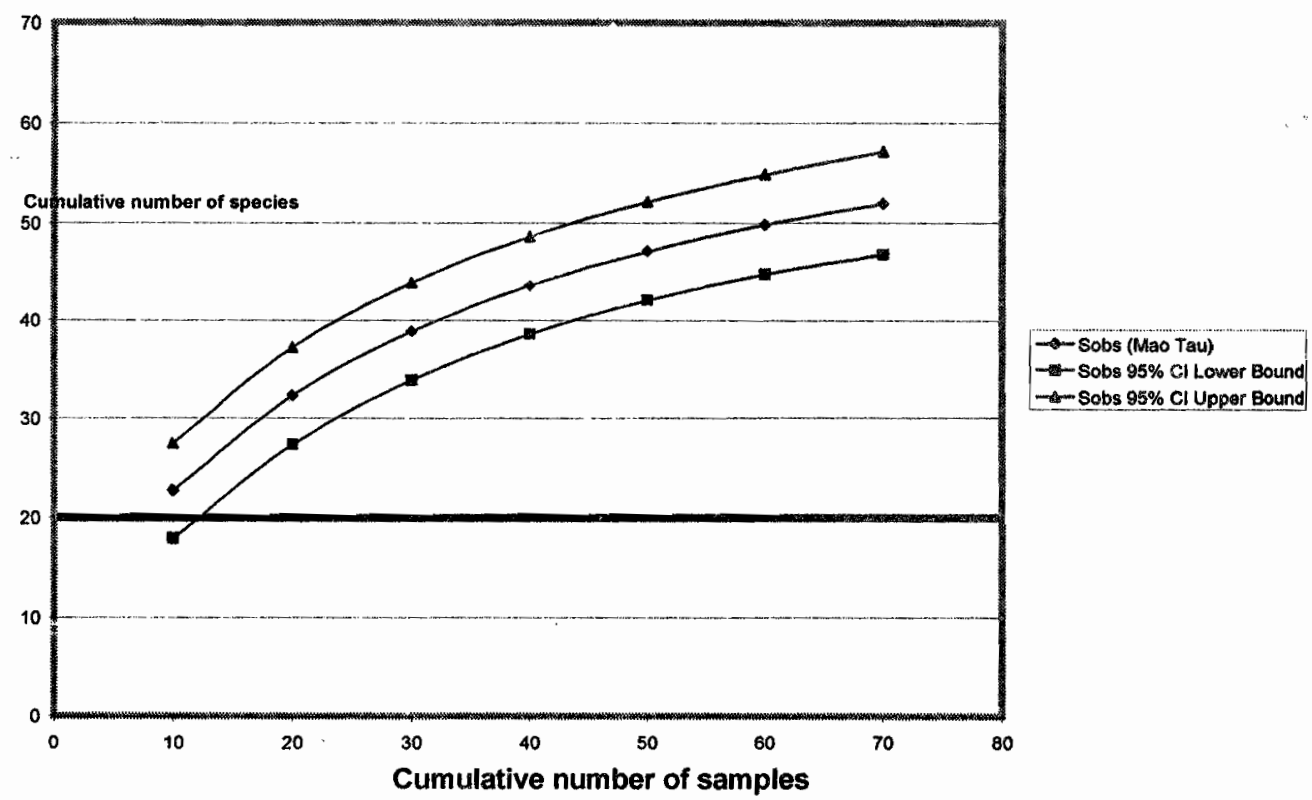

Figure 2: The mean species accumulation curve (observed species richness) for land snail richness in Odukpani based on 100 rand omized of sample order with $95 \%$ confidence band.

Table1: List of species recorded in each sample plot in Odukpani limestone cave

\begin{tabular}{|c|c|c|c|c|c|c|c|c|c|}
\hline & Piot 1 & & Plot 2 & $\begin{array}{l}\text { plot } \\
3 \\
\end{array}$ & $\begin{array}{l}\text { Plot } \\
4\end{array}$ & $\begin{array}{l}\text { Plot } \\
5 \\
\end{array}$ & $\begin{array}{l}\text { Plot } \\
6\end{array}$ & Plot 7 & Total \\
\hline \multicolumn{10}{|l|}{ Achatinidae } \\
\hline Archachátina marginata & 1 & 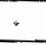 & 6 & 2 & 3 & 7 & & & 19 \\
\hline Lignus sp. & & & 1 & & & & & 1 & 2 \\
\hline Limicolaria flammea & & & & 1 & & & 1 & & 2 \\
\hline Limicolaria aurora & & & & & & & 5 & & 5 \\
\hline Pseudachatina sp. & & & & & & & & 1 & 1 \\
\hline \multicolumn{10}{|l|}{ Euconulidae } \\
\hline Afropunctum seminium & & & 1 & & 2 & & & & 3 \\
\hline \multicolumn{10}{|l|}{ Aillyidae } \\
\hline Aillya camerunensis & & & & 1 & 3 & & & & 4 \\
\hline \multicolumn{10}{|l|}{ Streptaxidae } \\
\hline Edentulina liberiana & & & & & 2 & & & & 2 \\
\hline Gonaxis camerunensis & & & & & 1 & & & & 1 \\
\hline Gulella buccholtzi & & & & & 1 & & & & 1 \\
\hline Gulella conospira & & & & & 1 & & & & 1 \\
\hline Gulella gemma & 4 & & 3 & 4 & 5 & 3 & 4 & 2 & 25 \\
\hline Gulella reesi & 11 & & 12 & 4 & 10 & 9 & 1 & & 47 \\
\hline Gulella fernandensis & 3 & & 6 & 7 & 5 & 2 & & & 23 \\
\hline Gulella monodon & 1 & & & & 2 & & & & 3 \\
\hline Gulella obani & 1 & & 1 & 1 & 1 & & & & 4 \\
\hline Gulella pupa & & & 1 & & & & & & 1 \\
\hline Gulella poensis & & & 1 & & 2 & 2 & 2 & & 7 \\
\hline Gulella sp. 1 & 1 & & 1 & & 1 & & & & 3 \\
\hline Gulella sp.2 & 1 & & & 1 & & & & & 2 \\
\hline Gulella sp. 3 & & & & & 1 & & & & 1 \\
\hline Gulella sp.4 & & & & 1 & & & & & 1 \\
\hline Ptychotrema aequatoriale & & & & 1 & & & & & 1 \\
\hline Ptychotrema anceyi & & & & & 1 & 2 & & & 3 \\
\hline Ptychotrema martensi & & & & & 1 & & & & 1 \\
\hline Ptychotrema sp. 1 & 1 & & 1 & & & & & & 2 \\
\hline Ptychotrema sp.2 & & & 1 & & 3 & 1 & & & 5 \\
\hline Ptychotrema sp. 3 & & & & 1 & & & & & 1 \\
\hline
\end{tabular}




\begin{tabular}{|c|c|c|c|c|c|c|c|c|c|c|}
\hline \multirow{2}{*}{\multicolumn{2}{|c|}{$\begin{array}{l}\text { Streptosteie sp. } \\
\text { juvenile Streptaxidae }\end{array}$}} & & & 1 & 1 & 3 & & & & 5 \\
\hline & & 5 & & & 4 & 6 & 4 & & & 19 \\
\hline & SUBULINIDAE & & & & & & & & & \\
\hline & Curvella sp. 1 & 7 & & 5 & 10 & 5 & 1 & & & 28 \\
\hline & Curvella sp2 & 1 & 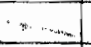 & & 1 & 1 & & & & 3 \\
\hline & Curvella sp. 3 & & & & 1 & & & 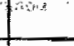 & & 1 \\
\hline & Homorus sp. & & & & & & & & 1 & 1 \\
\hline & Pseudopeas sp. 1 & 1 & & 2 & 2 & 6 & 3 & 1 & & 15 \\
\hline & Pseudopeas sp.2 & 1 & & 2 & . & 1 & & & & 4 \\
\hline & Pseudopeas sp. 3/strongly ribbed) & & & & & & & & 2 & 2 \\
\hline & Pseudoglessula sp. 1 (strongly r) & 1 & & & & 4 & 3 & & & 8 \\
\hline & Pseudoglessula sp. 2 (strongly r) & & & & 2 & 1 & & & & 3 \\
\hline & Pseudoglessula sp. 3 & & & & 4 & 1 & & & & 5 \\
\hline & Subulina sp. 1 & & & 4 & 3 & 2 & 1 & & & 10 \\
\hline & Subulina sp.2 & & & & & 1 & & & & 1 \\
\hline & Subuiumasp. & & & & & & & & 1 & 1 \\
\hline & juvenile Subulinidae & 8 & & & & 2 & & & & 10 \\
\hline & Urocyclidae & & & & & & & & & \\
\hline & Thapsia sp. & & & 1 & 1 & & & & & 2 \\
\hline & Trochozonites calabaricus & & & 1 & 1 & 4 & 8 & 5 & 8 & 27 \\
\hline & Trochozonites sp.1 & $\underline{2}$ & & 14 & 17 & 10 & 11 & & 3 & 57 \\
\hline & Trochozonites sp.2 & 5 & & 10 & 2 & 1 & & & & 18 \\
\hline & Trochozonites sp.3 & & & 1 & 1 & 1 & 2 & & & 5 \\
\hline & Trochozonites sp. 4 hairy & & & & & 1 & 3 & & & 4 \\
\hline & Maizaniidae & & & $i$ & & & & & & \\
\hline & Maizania sp. 1 & 1 & & 3 & 10 & 1 & 1 & & & 16 \\
\hline & Maizania sp. 2 & & & 1 & .1 & & 2 & & & 4 \\
\hline & Maizania sp3 & & & & & 3 & & & & 3 \\
\hline & Veronicellidae & & & & & & & & & \\
\hline & Pseudoveronicella liberiana & & & & & 1 & 1 & & & 2 \\
\hline & Total no. of individuals & 56 & & 80 & 85 & 100 & 66 & 19 & 19 & 425 \\
\hline & Total no. of species/plot & 17 & & 24 & 26 & 34 & 18 & 7 & 8 & \\
\hline
\end{tabular}

Eight snail families were represen.ed, of which the most prominent was the carnivorous Streptaxidae The streptaxids dominated the molluscan fauna in diversity of species and number of individuals. Twenty-one $(40 \%)$ species and $158(37 \%)$ individuals of streptaxid land snails was recorded from the study area. Other families of land-snails recorded are herbivores and detritivores. Few species were abundant except Trochozonites sp.1 (5t individuals), Gulclla reesi (47 individuals), Curvella sp.1 (28, individuals), Trochozonites calabaricus (27 individuals), Gulella gemma (25 individuals) and $G$. fernandensis (23 indiviciuals). Only one species, G. gemma, occurred in all the plots as most species had a narrow range of distribution. The second order, nonparametric jackknife richness estimator predicted a species richness of 72 (SD, 3.07) species while the Chao 2, nonparametirc species richness estimator predicted 64 (SD, 4.75) species based on 100 randomisation of the data for all the plots.

\section{DISCUSSION}

Land-use change is projected to lave the largest global impact on biodiversity, followed by climate cirange, nitrogen deposition, species introductions and changing concentrations of atmospheric $\mathrm{CO}_{2}$ (Sala et al 2000). Species diversity has functional consequences because the number and kinds of species present determine the organismal liaiis that influence ecosystem processes. The components of species diversity that determine this exprassion of laxits include the number of species present (specios richnoes), ti $i_{i t}$ relative abundances (species evenness), the particular species present (species composition), the interactions among species (non-additive effects), and the temporal and spatial variation in these properties. In addition to its effects on current functioning of ecosystems, species diversity influences the resilience and resistance of ecosystems to environmental change (Chapin et al., 2000)

Studies on the land snail fauna of a threatened limestone formation in Odukpani, near Calabar, Nigeria revealed high species richness in spite of low abundances. We recorded 52 species and 425 individuals from seven plots in a limestone cave. Majority of these species seem to be new to science or represent new recurds of their existence in Nigeria. We recorded two species of Maizaniidae and seven species of Streptaxidae that have not been seen elsewhere in Nigeria. This is perhaps one of the richest sites for land snail diversity recorded so far in Nigeria bearing in mind that this was a single-season survey. Cameron et at (2003) noted that a single-season survey of $16-20$ plots in Cameroon underestimated species richness by around $30 \%$. In Sabah, a single-season survey underestimated the fauna by $40 \%$. In Odukpani, like in Cameroon, a single-season survey underestimated the land mollusc fauna by almost $30 \%$ based un the fact that the species accumulation curve did not reach an asymptote but continue to rise with the addition of samples or individuals. It is believed that when further samples are collected, the species richness will increase and reach an ioymptote. Individual plots vary cortsiderably in specics riciness and composition. The richest plot contains about $50 \%$ of the fauna recorded for the whole site. This is similar to the ricliest plot in Cameroon (46\%) but much lower than the 
richest maquis plot $(85 \%)$ (Schiltuizen \& Rutjes, 2001 Cameron et al, 2003).

We have reason to suspect that the true diversity of Odukpani will lie higher than the $\mathbf{5 2}$ species reported. This is borne out by the fact that 14 species occurred as singletons indicating that there are many rare species to be discovered in the collection (Chazdon et al., 1998 and Colwell et al. 2004). This is shown by the estimation of true diversity using the nonparametric estimator Chao 2 (Chao 1987) and second-order jackknife (Smith \& Van Belle, 1984) which are suitable of small sample sizes as is the case here (Colwell \& Coddington, 1994; Gotelli \& Colwell, 2001). Chao 2 richness estimator and second-order jackknife gave estimates of 64.25 and 72.54 species respectively.

Comparatively, we found the same number of species as that recorded from 36 plots for Sabah, Malaysian Borneo (Schiltuizen \& Rutjes, 2001) and more than half of the species recorded for Cameroon (Winter \& Gittenberger, 1998). We recorded almost twice the number of species reported by Cameron et al. (2003) from fourtocn sampling plots and about two-third the species reported by Tattersfield et al. (2006) from 45 plots in Mwanhana Forest Reserve in Tanzania. The species richness in Odukpani is comparable only to that recorded for Cross River National Park, Oban hills sector, with 53 species and 636 individuals (Oke \& Alohan, 2004). Even at that, the species from Oban were collected from 24 sampling plots within a square kilometre during three sampling seasons. In Ehor, Edo State, Nigeria, Oke \& Alohan (2002) recorded 38 species and 1258 individuals from nine $20 \mathrm{~m}^{2}$ plots in a tropical rainforest. Also, Alohan \& Oke (2004) recorded 35 species and 316 individuals from five $20-\mathrm{m}^{2}$ plots in Okomu National Park, Edo State, Nigeria. We believe that this is one of the richest sites in Nigeria and may be comparable with other high biodiversity site in the world given the small sample size. Consequently, we advocate for the conservation of the unique biological diversity of the Odukpani limestone caves. It is also believed that when further studies are carried out in these caves, the full biological diversity potential of this region will be realised and appropriate measures for its conservation will be carried out in the near future.

\section{REFERENCES}

Alohan, F.I. and Oke, O.C., 2004. A preliminary investigation on the diversity and abundance of land molluscs in Okomu National Park, Edo State Nigeria. Journal of Applied and Basic Science 2: 77-81.

Boycott, E. 1934. The habitats of land Molitusca in Britain. Journal of Ecology 22: 1-34.

Cameron, R. A. D., 1992. Land snail faunas of the Napier and Oscar Ranges, Western Australia: Diversiiy, distribution and speciation. Biological Journal of the Linnaean Society, $45:$ 271-286.

Cameron, R. A. D., Mylonas, M., Triantis, K., Parmakelis, A. and Vardinoyannis, K., 2003. Land-snail diversity in a square kilometre of Cretan Maquis: modest species richness, high diversity and local homogeneity. Journal of Molluscan Studies 69: 93-99.

Chao, A., 1987. Estimating the population size for caplurerecapture data with unequal catchability. Bionetrics, 43: $783-791$.

Chapin, S, Zavaleta, E. S, Eviners, V. T., Nayor, R.L., Vltousek, P. M., Raynolds, H. L., Hooper, D. U., Lavorel, S., Sala, O. E., Hobbie, S. E., Mack, M. C. and Diaz, ¿., 2 CCo. Consequences of changing biodiversity. Nature 405 : 234-242.

Chazdon, R. L., R. K. Colwell, R. K., Denslow, J. S. and Guariguata, M. R., 1998. Statistical methods for estimating species richness of woody regeneration in primary and secondary rain forests of NE Costa Rica. Pn. 285-309 in F. Dallmeier and J. A. Comiskey, eds.

" Forest biodiversity "research. monitoring and modeling: Conceptual background and Old World case studies. Parthenon' Publishing, Paris.

Colwell, R. K., 2005 Estimates: Statistical estimation of species richoess and shared species from samples. Version 7.5. User's Guide and application published at: http://purl ocic.org/estimates.

Colwell, R. K. and Coddington, J. A., 1994. Estimating terrestrial biodiversity through extrapolation. Philosophical Transactions of the Royal Society (Series B) 345, 101-118.

Colwell, R. K., Mao, C. X. and Chang, J., 2004. Interpolating, extrapolating, and comparing incidence-based species accumulation curves. Ecology 85 : 2717 2727.

Crowther, J., 1987. Ecological observations in tropical karst terrain, West Malaysia III. Dynamics of the vegetation-soil-bedrock system. Journal of Biogeography 14: 157-164.

Gotelli, N. and Colwell, R. K., 2001. Quantifying biodiversity: Procedures and pitfalls in the measurement and comparison of species richness. Ecology Letters 4 . 379-391.

Groombridge, B., 1993. 1994 IUCN Red list of threatened animals. International Union for the conservation of Nature \& Natural Resources, Gland Switzerland, and Cambridge, U.K.

Lydeard, C., Cowie, R. H., Ponder, W. F., Bogan, A. E., Bouchet, P., Clark, S. A, Cummings, K. S., Frest, T. J., Gargominy, O., Herbert, D. G., Hershler, R., Perez, K. E., Roth, B., Seddon, M., Strong E. E. and Thompson, F. G., 2004. The global decline of nonmarine mollusks. Bioscience, 54:321-330

Magurran, A. E., 1980 . Ecological diversity and its measurement. London, Croom Helm, 179pp.

Nekola, J. C., Smith, T. A., Frest, T. J., 1996. Land snails of Door Pennisula natural habitats. Final report, Wisconsin Chapter, The Nature conservancy, Madison.

Oke, O. C. and Alohan, F. I., 2002. The land snail diversity in a square kilometerof tropical rainforest in Ehor, Edo State, Nigeria: modest species richness, hici abundance and :ocal heterogeneity. Journal of Environment, Science \& Health 5: 39-43.

Oke, O. C. and Alohan, F. I., 2004. Land snail diversity in a patch of rainforest in Cross river National Park: high species richness abundance and heterogeneity. Nigerian Journal of Applied Science, 22: 166-173.

O!stan A., Pearce, T. A. and Welter-Schultes, F., 2005. Land snail diversity in a threatened limestone district near Istanbul, Turkey. Animal biodiversity \& Conservation 28: 181-188.

Punder, W. F., 1997. Conservation status, threats and habitat requirements of Australian terrestrial and freshu:atar Mollusca. Memoirs of the Museum of Victoria 56 : 421-430.

Sala, E. O., Chapin, F. S, Armesto, J. J., Berlow, E. Bloomfield, J., Dirzo R., Huber-Sanwald, E., Huenneke, L. F., 
Jackson, R. B., Kinzig, A., Leemans R., Lodge, D. M. Mooney, H. A., Oesterheld, M., Poff, L. N., Sykes, M. T.

Walker, B. H., Walker, M. and Wall, D. H., 2000. Global biodiversity scenarios for the year 2010 . Science 287 : $1770-1774$

Schilthuizen, M. and Rutjes, H. A., 2001. Land snail diversity in a square kilometre of tropical rainforest in Sabah, Malaysian Borneo. Journal of Molluscan Studies, 67: 417-423.

Schiltuizen, M., Chai, H., Kimsin T. E., and Vermuelen J. J., 2003. Abundance and diversity of land-snails (Mollusca: Gastropoda) on limestone hills in Borneo. The Raffles Bulletin of Zoology 51: 35-42.
Smith, E.P. and Van Belle, G. 1984. Non-parametric estimation of species richness. Biometrics, 40: 119129.

Tattersfield, P., Seddon, M. B., Ngereza, C and Rowson B., 2006. Elevational variation in diversity and composition of land-snail faunas in a Tanzanian forest. African Journal of Ecology 44: 47-60.

Winter, A. J. De and Gittenberger, E., 1998. The land snail fauna of a square kilometre patch of rainforest in southwestern Cameroon: high species richness, low abundance and seasonal fluctuations. Malacologia, 40: $231-250$. 